Original Article

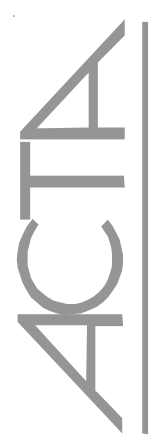

\title{
Methicillin-resistant Staphylococcus aureus on surfaces of an Intensive Care Unit*
}

\author{
Stapbylococcus aureus resistente à meticilina em superficies de uma Unidade de Terapia Intensiva
}

Staphylococcus aureus resistente a la meticilina en superficies de una Unidad de Cuidados Intensivos

\author{
Adriano Menis Ferreira ${ }^{1}$, Denise de Andrade ${ }^{2}$, Marcelo Alessandro Rigotti ${ }^{3}$, \\ Margarete Teresa Gottardo de Almeida ${ }^{4}$
}

\begin{abstract}
Objective: To evaluate the presence of methicillin-resistant Staphylococcus aureus (MRSA) in areas close to patients in a General Intensive Care Unit. Methods: This is a cross-sectional study, in which microbiological samples were collected from five surfaces (left / right bed siderails, bed crank, table, buttons on the infusion pump, and cotton gowns) from each of ten patient rooms, totaling 63 samples. To collect samples, the Petri Film ${ }^{\mathrm{TM}}$ Staph Express Count System 3M ${ }^{\mathrm{TM}}$ was used to screen for methicillin resistance, with the Mueller-Hinton agar supplemented with $4 \%$ sodium chloride and $6 \mu \mathrm{g} / \mathrm{ml}$ of oxacillin. Descriptive analysis was conducted to determine the frequency (n) and percentage (\%) of contamination of environmental surfaces. Results: Of 48 samples positive for Staphylococcus aureus, 29 (60.4\%) were resistant to methicillin. The incidence on the siderails and bed cranks, table, buttons on the infusion pumps and aprons were, respectively, 55.5\%, $57.1 \%, 57.1 \%, 60.0 \%$ and $75.0 \%$. Conclusion: The results suggest that the surfaces around the patient constitute a major threat, as they represent secondary reservoirs of MRSA.

Keywords: Staphylococcus aureus; Equipment contamination; Cross infection; Methicillin resistance
\end{abstract}

\section{RESUMO}

Objetivo: Avaliar a presença de Staphylococcus aureus resistente à meticilina (MRSA) em superfícies próximas aos pacientes internados em uma Unidade de Terapia Intensiva Geral. Métodos: Trata-se de um estudo transversal, no qual foram coletadas amostras microbiológicas de cinco superfícies (grades direita/esquerda, manivela da cama, mesa, botões da bomba de infusão e aventais de algodão) de cada dez unidades de pacientes, totalizando 63 amostras. Para a coleta, foram utilizadas placas Petri Film ${ }^{\mathrm{TM}}$ Staph Express Count System $3 \mathrm{M}^{\mathrm{TM}}$ e para a triagem de resistência à meticilina, o ágar Mueller-Hinton adicionado de $4 \%$ de cloreto de sódio e $6 \mu \mathrm{g} / \mathrm{ml}$ oxacilina. Análises descritivas foram empregadas para determinar a frequência (n) e porcentagem (\%) de contaminação das superfícies ambientais. Resultados: Das 48 amostras positivas para Staphylococcus aureus, $29(60,4 \%)$ foram resistentes à meticilina. A incidência em grades e manivelas da cama, mesa, botões da bomba de infusão e aventais foi, respectivamente, 55,5\%, 57,1\%, 57,1\%, 60,0\% e 75,0\%. Conclusão: Os resultados sugerem que as superfícies ao redor do paciente constituí-se uma importante ameaça, visto que representam reservatórios secundários de MRSA.

Descritores: Staphylococcus aureus; Contaminação de equipamentos; Infecção hospitalar; Resistência à meticilina

\section{RESUMEN}

Objetivo: Evaluar la presencia de Staphylococcus aureus resistente a la meticilina (MRSA) en superficies cercanas a los pacientes internados en una Unidad de Cuidados Intensivos General. Métodos: Se trata de un estudio transversal, en el cual se recolectaron muestras microbiológicas de cinco superficies (enrejados derecho/izquierdo, manivela de la cama, mesa, botones de la bomba de infusión y mandiles de algodón) de cada diez unidades de pacientes, totalizando 63 muestras. Para la recolección, se utilizaron placas Petri Film ${ }^{\mathrm{TM}}$ Staph Express Count System $3 \mathrm{M}^{\mathrm{TM}}$ y para el triaje de resistencia a la meticilina, el agar Mueller-Hinton adicionado del $4 \%$ de cloruro de sodio y $6 \mu \mathrm{g} / \mathrm{ml}$ oxacilina. Se emplearon análisis descriptivos para determinar la frecuencia (n) y el porcentaje (\%) de contaminación de las superficies ambientales. Resultados: De las 48 muestras positivas para Staphylococcus aureus, 29 (60,4\%) fueron resistentes a la meticilina. La incidencia en enrejados y manivelas de la cama, mesa, botones de la bomba de infusión y mandiles fue, respectivamente, 55,5\%, 57,1\%, 57,1\%, 60,0\% y 75,0\%. Conclusión: Los resultados sugieren que las superficies alrededor del paciente se constituye en una importante amenaza, pues representan reservorios secundarios de MRSA. Descriptores: Staphylococcus aureus; Contaminación de equipos; Infección hospitalaria; Resistência a la meticilina

* Study carried out in October 2008 in a medical and general surgery Intensive Care Unit in a University Hospital. Part of a Project for Postdoctoral supported by National Counsel of Technological and Scientific Developmen (CNPq).

${ }^{1}$ RN, Ph.D in Nursing. Post-Doctorate degree in Nursing by the Nursing School of Ribeirão Preto, University of São Paulo. Professor at the College of Nursing of the Universidade Federal de Mato Grosso do Sul-Três Lagoas (MS) Brazil.

${ }^{2}$ RN. Full Professor at the Department of General and Specialized Nursing at University of São Paulo at Ribeirão Preto College of Nursing - Ribeirão Preto (SP), Brazil. WHO Collaborating Centre for Nursing Research Development.

${ }^{3}$ RN. Masters's Student in Nursing, University of São Paulo at Ribeirão Preto College of Nursing - Ribeirão Preto (SP), Brazil.

${ }^{4}$ Biologist, Ph.D. Professor at the Department of Infectious and Parasitic Dermatological Diseases at the Faculdade de Medicina de São José do Rio Preto and Head of the Laboratory of Microbiology at the Faculdade de Medicina de São José do Rio Preto (SP) Brazil.

Corresponding Author: Adriano Menis Ferreira

Received article 29/07/2009 and accepted 07/04/2011

Av. Ranulpho Marques Leal, 3220 - Distrito Industrial - Três Lagoas - MS - Brazil

CEP. 79610-100 E-mail: a.amr@ig.com.br 


\section{INTRODUCTION}

Staphylococcus aureus is among the microorganisms responsible for colonizing and infecting men. It is one of the main agents that cause primary bloodstream infections, lower respiratory tract and surgical site infections ${ }^{(1-2)}$ also being highlighted as the second major cause of nosocomial bacteremia ${ }^{(3)}$, pneumonia, and cardiovascular infections ${ }^{(1-2)}$. Infections caused by $S$. aureus are especially difficult to treat because of the profile of resistance to antimicrobial drugs. Resistance to penicillin and to the newer narrow-spectrum ?-lactamaseresistant penicillin antimicrobial drugs (e.g., methicillin, oxacillin) appeared almost immediately after introduction into clinical practice in the 1940s and 1960s, respectively ${ }^{(4)}$.

Methicillin-resistant Staphylococcus aureus (MRSA) is endemic within most hospitals across the globe and causes a significant degree of morbidity and mortality, especially in intensive care unit (ICU) patients ${ }^{(5)}$. ICU patients are at greater risk of infection with MRSA due to their multiple risk factors including extended hospital stays, high antibiotic consumption and presence of intravenous devices ${ }^{(6-7)}$.

The main vehicle through which patients acquire MRSA whilst on ICU is thought to be the hands of healthcare workers, but studies have demonstrated that, even with high compliance to hand hygiene measures, cross-transmission still occurs ${ }^{(8-9)}$. The precise role the inanimate environment plays in the transmission of MRSA is still not certain. The environment can act as a reservoir for MRSA, which can contaminate a wide variety of hospital equipment and surviving for prolonged periods of time ${ }^{(10-12)}$.

This study aimed to evaluate the presence of MRSA in surfaces near hospitalized patients in a General Intensive Care Unit.

\section{METHODS}

Cross-sectional study carried out in October 2008 in a medical and general surgery Intensive Care Unit in a University Hospital. The study ICU has 30 beds for patients over 18 years of age, with $100 \%$ occupation and an average monthly admission of 62 patients. The authorization of the administrative parties was obtained for its execution.

The four environmental surfaces (bed rails [right and left], crank, bedside table, buttons of infusion pump) and 13 surgical gallons in ten ICU patients units were selected for culture before cleaning. These objects were chosen because they are frequently touched, with potential for exposure to medical staff and patients. All five items were cultured once, in October 21, 2008, totaling 63 samples.

During the study the ten units had patients and it was not possible to characterize their profile. However, the average hospitalization length of stay of patients who were in the beds during data collection was 8.3 days.

Usually the patient unit is cleaned with cotton cloth soaked in $70 \%$ alcohol $(\mathrm{w} / \mathrm{v})$. If some dirt is observed, it is firstly cleaned with detergent and water, and then usual cleaning is performed. It is highlighted that the same cloth is used to clean different patient units and it is only changed when it is visibly dirty, with the exception of isolation rooms in the ICU.

Petri Film ${ }^{\mathrm{TM}}\left(3 \mathrm{M}^{\mathrm{TM}}\right.$, St Paul, MN, USA) Staph Express $3 \mathrm{M}^{\mathrm{TM}}$ plates prepared with modified Baird-Parker chromatogenic medium, Staphylococcus aureus selective and differential, were used for collection of microorganisms. The plates were pressed onto the surface for 1 minute at a pressure of $\sim 25 \mathrm{~g} / \mathrm{cm}^{2}$ (tested by pressing a control plate onto the surface of a top pan balance) without movement.

At the end of each collection, plates were identified with: date, time and place of collection, stored in polystyrene boxes and transported to the Laboratory of Microbiology.

A sampling area of $30 \mathrm{~cm}^{2}$ and incubation at $35^{\circ} \mathrm{C}$ during 24-48h was adopted for Petrifilm ${ }^{\mathrm{TM}}$ model. Reading of Petrifilm ${ }^{\mathrm{TM}}$ plates was done using stereomicroscope (Nikon, JP) under reflected light and were quantitatively evaluated through the CFU (Colony Forming Units). Red-violet colonies were considered as Staphylococcus aureus.

Methicillin susceptibility was tested by the oxacillin resistance screening test ${ }^{(13)}$. Petri plates containing MullerHinton agar, added with 4\% Sodium Chloride and $6 \mu \mathrm{g} /$ $\mathrm{ml}$ oxacillin, known as MRSA medium (Probac do Brasi ${ }^{\mathbb{R}}$ ), were used. These microorganisms were transplanted in $\mathrm{BHI}$ (Brain Heart Infusion) broth and incubated at $37^{\circ} \mathrm{C}$ for 24 hours. After this period they were inoculated in plates and incubated at $37^{\circ} \mathrm{C}$ for 24 and 48 hours. Any growing in the plate was considered MRSA.

Descriptive analyses were used to determine the frequency ( $\mathrm{n}$ ) and percentage (\%) of contamination of environmental surfaces.

\section{RESULTS}

This study demonstrated contamination of environmental surfaces through collection of microbiological samples of 63 surfaces near patients hospitalized in the ICU. From the 48 positive Staphylococcus aureus samples, 29 (60.4\%) were methicillin-resistant. The incidence on bed rails and cranks, bedside table, buttons of infusion pump and surgical gallons were, respectively, $55.5 \%, 57.1 \%, 57.1 \%, 60.0 \%$ and $75.0 \%$ (Table 1).

Widespread environmental contamination with MRSA on the ICU (Figure 1) was found. 
Table 1 - Contamination by Staphylococcus aureus and methicillin-resistant Staphylococcus aureus in surfaces near patients in intensive care unit

\begin{tabular}{lccrrc}
\hline Examined surfaces & Number of samples & S. aureus & $\mathbf{\%}$ & MRSA & $\mathbf{\%}$ \\
\hline Bed rails (right and left) & 20 & 18 & 90.0 & 10 & 55.5 \\
Bedside table & 10 & 7 & 70.0 & 4 & 57.1 \\
Bed crank & 10 & 7 & 70.0 & 4 & 57.1 \\
Infu sion pump button & 10 & 5 & 50.0 & 3 & 60.0 \\
Surgical gallons & 13 & 8 & 61.5 & 6 & 75.5 \\
Total & 63 & 48 & 76.1 & 29 & 60.4 \\
\hline
\end{tabular}

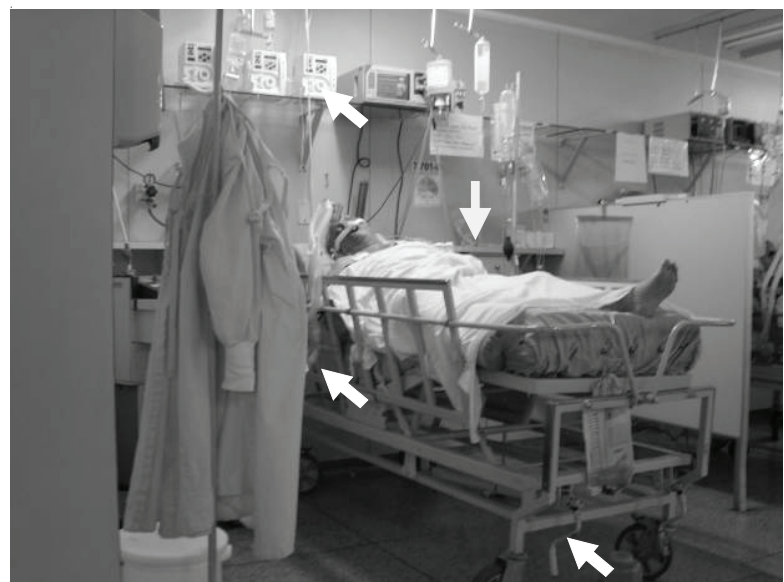

Figure 1 - View of MRSA contaminated surfaces in ICU patient unit.

\section{DISCUSSION}

Numerous studies illustrate that many different inanimate surfaces in hospitals can become a reservoir for MRSA ${ }^{(14-18)}$. Several studies specifically address environmental MRSA contamination within isolation units $^{(19-21)}$.

For several decades, there has been considerable controversy over whether or not contaminated environmental surfaces contribute to transmission of healthcare-associated pathogens. The potential for contaminated environmental surfaces to contribute to transmission of healthcare-associated pathogens depends on a number of factors, including the ability of pathogens to remain viable on a variety of dry environmental surfaces, the frequency with which they contaminate surfaces commonly touched by patients and healthcare workers, and whether or not levels of contamination are sufficiently high to result in transmission to patients ${ }^{(22)}$.

Contamination of surrounding surfaces was evident in $48(76.1 \%)$ of the occasions when samples were obtained. Altogether, the frequency of MRSA positive environmental sites was $60.4 \%$. Other studies on this topic have reported lower contamination rates in isolation rooms, such as $27.0 \% \%^{(19)}, 24.0 \% 0^{(23)}, 40.0 \% 0^{(24)}$,
$22.0 \%{ }^{(20)}$, and $54.0 \%{ }^{(21)}$.

However, the various studies of MRSA detection on surfaces in isolation rooms are hardly comparable, since the patient characteristics, the microbiological screening methods, the sampling regimen, as well as the manner, frequency, and effectiveness of cleaning and disinfection methods vary considerably.

There is as yet no direct proof that the environment acts as a secondary reservoir for the infection of patients with multidrug-resistant bacteria in epidemics or endemic situations. However, there is mounting evidence that the environment of patients colonized with Grampositive bacteria serves as a potential reservoir for crosstransmission and hence possible infection ${ }^{(19,25)}$.

Environmental contamination may contribute to transmission of healthcare pathogens when healthcare workers contaminate their hands or gloves by touching contaminated surfaces, or when patients come into direct contact with contaminated surfaces ${ }^{(19)}$.

Contaminated environmental surfaces that are commonly touched by patients and/or staff may act as sources for hand transfer. In support of this, Boyce et $\mathrm{al}^{(19)}$. demonstrated that five $(42 \%)$ of 12 nurses contaminated their gloves with MRSA while performing activities that required no direct patient contact but involved touching objects in the rooms of MRSA patients. Oie et $\mathrm{al}^{(14)}$. found MRSA on the door handles of $19 \%$ of 21 rooms MRSA patients but also on $7 \%$ of door handles of 175 non-MRSA rooms. French et al. ${ }^{(26)}$, demonstrated that MRSA was found before cleaning on $59 \%$ of 27 door handles and $33 \%$ of nine sink taps. MRSA also was found on other sites commonly touched by staff, such as bed-raising control panels, light switches and patient hoists. In another study, $31 \%$ of volunteers who touched bed rails and overbed tables in patient rooms contaminated their hands with $S$. aureus $\left(35 \%\right.$ of which were MRSA) ${ }^{(27)}$. When volunteers touched bed rails and overbed tables in unoccupied rooms that had been terminally cleaned, $7 \%$ contaminated their hands with $S$. aureus ${ }^{(27)}$.

The high incidence of contamination of the surgical gallons in this study calls attention. It is highlighted that the surgical gallons were $100 \%$ cotton, for individual 
use for each patient, replaced every 24 hours or when visibly wet/dirty, however, they were in use for approximately 18 hours and were used by different professionals (nursing, staff nursing, physicians and physical therapists) who examined or delivered care to patients who were under contact precaution. This can have contributed to this reality.

Transmission of MRSA from contaminated environmental sources to patients has occurred in a variety of settings. Schultsz et al. ${ }^{(28)}$ presented convincing evidence that ultrasonic nebulizers were the source of an MRSA outbreak among patients. Other studies have provided suggestive evidence that contaminated ventilation grills were sources of MRSA outbreaks in hospitals ${ }^{(29-30)}$. In a study by Hardy et al. ${ }^{(20)}$ the authors concluded that three patients acquired MRSA from the environment, but did not exclude Health Care Workers (HCWs) as another potential source ${ }^{(28-31)}$. The role of contaminated environmental surfaces in transmission of healthcareassociated pathogens is also supported by the fact that cleaning and/or disinfection of the environment can reduce the incidence of healthcare-associated colonization or infection, however, evidence for the effect of basic cleaning on reducing the acquisition rate of MRSA in hospital is scant, however a recent study have demonstrated that an intervention consisting of increased application of quaternary ammonium disinfectant (immersion of the cleaning cloth in buckets), Environmental Services staff education, and the use of a black-light monitoring system improved cleaning and decreased the likelihood of cultures positive for either MRSA or Vancomycin-Resistant Enterococcus (VRE) ${ }^{(32)}$.

Microbiological sampling of surfaces may be helpful in testing the effectiveness of new or modified cleaning or disinfection procedures. It may also be conducted in response to epidemiological investigations which suggest that environmental or medical-device surfaces may be reservoirs or sources of nosocomial disease transmission ${ }^{(33)}$. The aim of cleaning should be to keep surfaces visibly clean, to disinfect frequent-touch surfaces more frequently than non-frequent-touch surfaces, and to clean up spills promptly ${ }^{(34-35)}$. Thus, near patient (e.g. chart tables, bed frames) and frequent-touch (bed crank, bed rail, Infusion pump button) environmental surfaces may become contaminated with epidemiologically important microbes and should be cleaned regularly and at patient discharge as per hospital policy.

In a study ${ }^{(36)}$ nursing professionals showed lack of knowledge about the principle reservoirs for multiple drug resistant bacteria implicating in the possibility of exposure of professionals to these factors without the proper precautions and consequently, the risk of contamination and dissemination of these multiple drug resistant bacteria.
In this study, the high incidence of environmental contamination are likely to be a reflection of both poor hand hygiene practices and compromised hygiene measures, as, during the study, no cleaning procedure was observed on the analyzed surfaces, although the routine is to disinfect using 70 percent alcohol once a day, after patients' discharge or death. The recorded levels of contamination in this study could reflect a need to re-iterate the importance of basic hand hygiene measures and the higher bacterial contamination rates in our study could suggest that the current method of cleaning may not be fit for purpose and consideration should be given to use of disinfectant or other agents, as a routine practice to reduce bioburden in addition to more intensive cleaning regimens.

This study has limitations. First, cultures were taken only time. The exact timing between when an object was cleaned, when it was contacted, and when it was cultured was not quantified. These timing details may have had a dramatic effect on the final culture results. The number of times an object was touched also was not recorded. Moreover, a convenience sample of only five objects does not represent the ICU as a whole and there may be items that might haven't been positive for MRSA but were not sampled. Financial restraints limited the amount of samples taken.

Further investigation of the clinical significance of hospital environmental contamination and of more effective cleaning methods are required. What remains inconclusive, however, is the larger significance of environmental contamination with pathogenic bacteria such as MRSA, especially in terms of epidemiological concerns related to nosocomial infections.

\section{CONCLUSION}

The results of this preliminary cross-sectional screening study provides evidence of a high incidence of bacterial contamination and suggest that the environment surrounding patients may be significantly contaminated with S. aureus (MRSA) and that surfaces could represent an important reservoir in the transmission of MRSA. Contaminated surfaces contribute to transmission of healthcare-associated pathogens by serving as sources of hand (or glove) contamination among healthcare workers, and by direct spread of pathogens to susceptible patients. An increasing body of evidence suggests that enhanced cleaning/disinfection of environmental surfaces can reduce transmission of these pathogens. This study also identifies a potential inanimate object, ubiquitously present in many patient environments, which could be used as a marker of environmental contamination. This should allow the further study of the effectiveness of interventions and the causal relationship to clinical outcomes. 


\section{REFERENCES}

1. Richards MJ, Edwards JR, Culver DH, Gaynes RP. Nosocomial infections in medical intensive care units in the United States. National Nosocomial Infections Surveillance System. Crit Care Med. 1999;27(5):887-92.

2. Richards MJ, Edwards JR, Culver DH, Gaynes RP. Nosocomial infections in pediatric intensive care units in the United States. National Nosocomial Infections Surveillance System. Pediatrics. 1999;103(4):e39.

3. Wisplinghoff H, Bischoff T, Tallent SM, Seifert H, Wenzel RP, Edmond MB. Nosocomial bloodstream infections in US hospitals: analysis of 24,179 cases from a prospective nationwide surveillance study. Clin Infect Dis. 2004;39(3):309-17. Erratum in: Clin Infect Dis. 2004;39(7):1093. Clin Infect Dis. 2005;40(7):1077.

4. Lowy FD. Antimicrobial resistance: the example of Staphylococcus aureus. J Clin Invest. 2003;111(9):126573.

5. Diekema DJ, Pfaller MA, Schmitz FJ, Smayevsky J, Bell J, Jones RN, et al. Survey of infections due to Staphylococcus species: frequency of occurrence and antimicrobial susceptibility of isolates collected in the United States, Canada, Latin America, Europe, and the Western Pacific region for the SENTRY Antimicrobial Surveillance Program, 1997-1999. Clin Infect Dis. 2001;32 Suppl 2:S11432.

6. Asensio A, Guerrero A, Quereda C, Lizán M, MartinezFerrer M. Colonization and infection with methicillinresistant Staphylococcus aureus: associated factors and eradication. Infect Control Hosp Epidemiol. 1996;17(1):20-8.

7. Ibelings MM, Bruining HA. Methicillin-resistant Staphylococcus aureus: acquisition and risk of death in patients in the intensive care unit. Eur J Surg. 1998;164(6):411-8.

8. Pittet D, Mourouga P, Perneger TV. Compliance with handwashing in a teaching hospital. Infection Control Program. Ann Intern Med. 1999;130(2):126-30.

9. Pittet D, Dharan S, Touveneau S, Sauvan V, Perneger TV. Bacterial contamination of the hands of hospital staff during routine patient care. Arch Intern Med. 1999;159(8):821-6.

10. Blythe D, Keenlyside D, Dawson SJ, Galloway A. Environmental contamination due to methicillin-resistant Staphylococcus aureus (MRSA). J Hosp Infect. 1998;38(1):67-9. Comment in: J Hosp Infect. 19981;39(3):242-3. J Hosp Infect. 1998;39(3):243-4.

11. Ferreira AM, Andrade D, Almeida MTG, Cunha KC, Rigotti MA. Colchões do tipo caixa de ovo: um reservatório de Staphylococcus aureus resistente à meticilina? Rev Esc Enferm USP. 2011;45(1):161-6.

12. Oie S, Kamiya A. Contamination of environmental surfaces by methicillin-resistant Staphylococcus aureus (MRSA). Biomed Lett. 1998;57:115-9.

13. NCCLS. Performance standards for antimicrobial susceptibility testing. Fourteenth informational supplement. NCCLS document M100-S14. 2004, Wayne, Pennsylvania.

14. Oie S, Hosokawa I, Kamiya A. Contamination of room door handles by methicillin-sensitive/methicillin-resistant Staphylococcus aureus. J Hosp Infect. 2002;51(2):140-3.

15. Oie S, Yanagi C, Matsui H, Nishida T, Tomita M, Kamiya A. Contamination of environmental surfaces by Staphylococcus aureus in a dermatological ward and its preventive measures. Biol Pharm Bull. 2005;28(1):120-3.

16. Panhotra BR, Saxena AK, Al-Mulhim AS. Contamination of patients' files in intensive care units: an indication of strict handwashing after entering case notes. Am J Infect Control. 2005;33(7):398-401.

17. Fellowes C, Kerstein R, Clark J, Azadian BS. MRSA on tourniquets and keyboards. J Hosp Infect. 2006;64(1):86-8.

18. Oomaki M, Yorioka K, Oie S, Kamiya A. Staphylococcus aureus contamination on the surface of working tables in ward staff centers and its preventive methods. Biol Pharm Bull. 2006;29(7):1508-10.

19. Boyce JM, Potter-Bynoe G, Chenevert C, King T. Environmental contamination due to methicillin-resistant Staphylococcus aureus: possible infection control implications. Infect Control Hosp Epidemiol. 1997;18(9):622-7.

20. Hardy KJ, Oppenheim BA, Gossain S, Gao F, Hawkey PM. A study of the relationship between environmental contamination with methicillin-resistant Staphylococcus aureus (MRSA) and patients' acquisition of MRSA. Infect Control Hosp Epidemiol. 2006;27(2):127-32.

21. Sexton T, Clarke P, O’Neill E, Dillane T, Humphreys H. Environmental reservoirs of methicillin-resistant Staphylococcus aureus in isolation rooms: correlation with patient isolates and implications for hospital hygiene. J Hosp Infect. 2006;62(2):187-94.

22. Boyce JM. Environmental contamination makes an important contribution to hospital infection. J Hosp Infect. 2007;65 Suppl 2:50-4.

23. Lemmen SW, Häfner H, Zolldann D, Amedick G, Lütticken R. Comparison of two sampling methods for the detection of gram-positive and gram-negative bacteria in the environment: moistened swabs versus Rodac plates. Int J Hyg Environ Health. 2001;203(3):245-8.

24. Asoh N, Masaki H, Watanabe H, Watanabe K, Mitsusima $\mathrm{H}$, Matsumoto K, et al. Molecular characterization of the transmission between the colonization of methicillinresistant Staphylococcus aureus to human and environmental contamination in geriatric long-term care wards. Intern Med. 2005;44(1):41-5.

25. Talon D. The role of the hospital environment in the epidemiology of multi-resistant bacteria. J Hosp Infect. 1999;43(1):13-7.

26. French GL, Otter JA, Shannon KP, Adams NM, Watling D, Parks MJ. Tackling contamination of the hospital environment by methicillin-resistant Staphylococcus aureus (MRSA): a comparison between conventional terminal cleaning and hydrogen peroxide vapour decontamination. J Hosp Infect. 2004;57(1):31-7.

27. Bhalla A, Pultz NJ, Gries DM, Ray AJ, Eckstein EC, Aron DC, Donskey CJ. Acquisition of nosocomial pathogens on hands after contact with environmental surfaces near hospitalized patients. Infect Control Hosp Epidemiol. 2004;25(2):164-7.

28. Schultsz C, Meester HH, Kranenburg AM, Savelkoul PH, Boeijen-Donkers LE, Kaiser AM, et al. Ultra-sonic nebulizers as a potential source of methicillin-resistant Staphylococcus aureus causing an outbreak in a university tertiary care hospital. J Hosp Infect. 2003;55(4):269-75.

29. Cotterill S, Evans R, Fraise AP. An unusual source for an outbreak of methicillin-resistant Staphylococcus aureus on an intensive therapy unit. J Hosp Infect. 1996;32(3):207-16.

30. Kumari DN, Haji TC, Keer V, Hawkey PM, Duncanson V, Flower E. Ventilation grilles as a potential source of methicillin-resistant Staphylococcus aureus causing na outbreak in an orthopaedic ward at a district general 
hospital. J Hosp Infect. 1998;39(2):127-33.

31. Rampling A, Wiseman S, Davis L, Hyett AP, Walbridge AN, Payne GC, Cornaby AJ. Evidence that hospital hygiene is important in the control of methicillin-resistant Staphylococcus aureus. J Hosp Infect. 2001;49(2):109-16.

32. Goodman ER, Platt R, Bass R, Onderdonk AB, Yokoe DS, Huang SS. Impact of an environmental cleaning intervention on the presence of methicillin-resistant Staphylococcus aureus and vancomycin-resistant enterococci on surfaces in intensive care unit rooms. Infect Control Hosp Epidemiol. 2008;29(7):593-9.

33. Al-Hamad A, Maxwell S. How clean is clean? Proposed methods for hospital cleaning assessment. J Hosp Infect. 2008;70(4):328-34.

34. Sehulster L, Chinn RY; CDC; HICPAC. Guidelines for environmental infection control in health-care facilities. Recommendations of CDC and the Healthcare Infection Control Practices Advisory Committee (HICPAC). MMWR Recomm Rep. 2003;52(RR-10):1-42.

35. Hota B. Contamination, disinfection, and cross-colonization: are hospital surfaces reservoirs for nosocomial infection? Clin Infect Dis. 2004;39(8):1182-9.

36. Moura JP, Gir E. Nursing staff knowledge of multi-resistant bacterial infections. Acta Paul Enferm. 2007;20(3):351-6. 